\title{
Complexity of the human whole saliva proteome
}

\author{
C. Hirtz, F. Chevalier, D. Centeno' ${ }^{1}$, J. C. Egea, \\ M. Rossignol ${ }^{1}$, N. Sommerer ${ }^{1}$ and Deville de Périère \\ Laboratoire de Physiologie, UFR d'Odontologie, Université Montpellier 1, \\ 545 avenue du Prof. J. L Viala, 34193 Montpellier and ${ }^{1}$ UR 1199, Laboratoire de \\ Protéomique, Institut National de la Recherche Agronomique, Montpellier, France
}

(Received on January 31, 2005)

\begin{abstract}
C. HIRTZ, F. CHEVALIER, D. CENTENO, J. C. EGEA, M. ROSSIGNOL, N. SOMMERER and DEVILLE DE PÉRIÈRE. Complexity of the human whole saliva proteome. J. Physiol. Biochem., 61 (3), 469-480, 2005.

Recent characterization of the whole saliva proteome led to contradictory pictures concerning the complexity of its proteome. In this work, 110 proteins were analysed by mass spectrometry allowing the identification of 10 accessions previously not detected on protein two-dimensional maps, including myosin heavy chain (fast skeletal muscle, IIA and IIB), phosphatidylethanolamine binding protein, secretory actin-binding protein precursor and triosephosphate isomerase. Further comparison with available data demonstrated simultaneously a low diversity in terms of variety of accessions and a high complexity in terms of number of protein spots identifying the same accession, the two thirds of identified spots corresponding to amylases, cystatins and immunoglobulins. This diversity may be of interest in the development of non invasive diagnostic tool for several disease.
\end{abstract}

Key words: Saliva, Protein processing, Proteomics, Mass spectrometry, Human.

Whole saliva is a mixture of secreted fluids having three main origins: the major and minor salivary glands (for ca 90\%), and the gingival crevicular fluid (for ca $10 \%$ ) by filtration through tight junctions, passive diffusion and exudation of plasma in the oral cavity $(14,16)$. Accordingly, it constitutes a quite complex bio-

Correspondence to C. Hirtz (Tel.: +33 (0) 046710 74 31; Fax: +33 (0) 04671045 89; email: christophe. hirtz@univ-montp1.fr). logical fluid containing a variety of both inorganic and organic components, such as minerals, lipids, growth factors, hormones and an array of proteins (10). Whole saliva is known to have important physiological functions and to play a significant role in oral homeostasis (16). However, overall biochemical and molecular characterization of saliva remains quite limited, whilst such data would be highly desirable to increase our knowledge in terms of physiology. Further- 
more, saliva can be collected easily, in a non-invasive way. In this view, saliva could have an high potential for the development of novel diagnostic tests (5).

Whole saliva is composed of different components among which protein is most abundant. As a consequence, it is of crucial importance to better understand its physiological functions, which could offer important benefits of potential use in clinical medicine. For a long time, most available information about salivary proteins relied on dedicated techniques having no large scale capacity for protein identification $(2,3,6,17,19)$. However, very recently, three works introduced a proteomic technology, combining resolutive two-dimensional electrophoresis and mass spectrometry, to map whole saliva proteins. Accordingly, the saliva proteome was firstly shown to display a relatively simple pattern with 7 accessions identified in 10 protein spots (21). By opposition, in two other works, a much more complex situation was described (7, 20). In these cases, 20 to 35 accessions were identified within one hundred of protein spots. The most striking result correspond to redundant spots like $\alpha$ amylase, cystatins, a prolactin inducible protein and zinc- $\alpha_{2}$-glycoprotein. Therefore, available proteomic characterizations lead to different pictures that are intriguing in several aspects. On a proteomic point of view, the occurrence of co-migrating spots is usually taken as frequent (8), and, on another hand, the observation of multiple spots for a same accession is attributed to post-translational modifications or event degradations. With respect to saliva, the observed proteome can be discussed in terms of posttranslational modifications for a part of accessions. For others, like $\alpha$-amylase, when the occurrence of isoforms is fre- quent (2), redundancy can not be ascribed from aforementioned post-translational modification nor protein degradation. In this case, an additional possible mechanism would rely on bacterial degradation (7). This could deeply affect any strategy in search for biological markers in clinical applications.

The goal of this study was to investigate the complexity of the whole saliva proteome. For this purpose, two-dimensional maps displaying $c a .700$ spots were established and characterized by MALDITOF MS.

\section{Material and Methods}

Chemicals.- Dry cover fluid, $180 \mathrm{~mm}$ immobiline dry strip gels and IPG buffer were from Amersham Biosciences (Orsay, France). Urea, thiourea, CHAPS, DTE, DTT, TRIZMA base, glycerol, SDS, iodoacetamide, ammonium persulfate, TEMED, glycine, agarose, $\beta$-mercaptoethanol, molecular weight markers, ammonium sulfate, $\alpha$-cyano-4-hydroxycinnamic acid, HPLC grade acetonitrile and trifluoroacetic acid were purchased from SIGMA (L'Isle d'Abeau, France). Microsep 3K were from Pall (Ann Arbor, USA). $30 \%$ acrylamide/bis $(37.5: 1 \mathrm{w} / \mathrm{w})$ and Coomasssie blue G-250 were from Bio-Rad (Richmond, USA). The kit to measure protein concentration was from Pierce (Rockford, USA), the protease inhibitor cocktail from Roche (Meylan, France), modified sequencing grade trypsin from Promega (Charbonnieres, France) and C18 Zip-Tip ${ }^{\mathrm{TM}}$ from Millipore (Bedford, USA).

Saliva collection and protein extraction.- Parafilm-stimulated whole saliva was collected 2 hours after usual breakfast time (17) and complemented with a pro- 
tease inhibitor cocktail. Saliva samples were centrifuged at $10,000 \times \mathrm{g}$ for $15 \mathrm{~min}$, and the supernatant was frozen at $-80^{\circ} \mathrm{C}$.

Protein were precipitated using $90 \%$ acetone (v/v), $10 \%(\mathrm{v} / \mathrm{v})$ TCA solution $(100 \% \mathrm{w} / \mathrm{v})$ and $0.07 \%$ 2-mercaptoethanol $(\mathrm{v} / \mathrm{v})$. After incubation at $-20^{\circ}$ $\mathrm{C}$ for 2 hours, insoluble material was pelleted at $37000 \mathrm{~g}$ with an Allegra 64-R centrifuge (Beckman Coulter, CA, USA). Pellets were washed three times with pure acetone containing $\quad 0.07 \% \quad 2$-mercatoethanol $(\mathrm{v} / \mathrm{v})$, air dried and solubilised in buffer containing $9 \mathrm{M}$ urea, $4 \%$ CHAPS (w/v), $0.05 \%$ Triton X100 (v/v) and $65 \mathrm{mM}$ DTT. Protein amount was estimated using the Bradford method (4).

Tro-dimensional gel electrophoresis.Precast IPG strips with nonlinear immobilized $\mathrm{pH}$ 3-10 gradient were rehydrated overnight with $200 \mathrm{mg}$ of protein sample complemented with $0.0025 \% \mathrm{v} / \mathrm{v}$ bromophenol blue and $1 \% \mathrm{v} / \mathrm{v}$ IPG buffer. Isoelectric focusing was carried out using the IPGphor ${ }^{\mathrm{TM}}$ isoelectric focusing system (Amersham Biosciences, Orsay, France) : $500 \mathrm{~V}(1 \mathrm{~h}), 1000 \mathrm{~V}(2 \mathrm{~h})$, linear gradient from $1000 \mathrm{~V}$ to $8000 \mathrm{~V}$, and a final phase at $8,000 \mathrm{~V}$ for $5 \mathrm{~h}$, resulting in a total of $c a 50,000$ V.h. Thereafter, strips were equilibrated for $15 \mathrm{~min}$ in $9 \mathrm{M}$ urea, $50 \mathrm{mM}$ Tris $\mathrm{HCl}$ buffer at $\mathrm{pH} 8.8,30 \%$ v/v glycerol, $2 \%$ SDS, $0.001 \mathrm{w} / \mathrm{v}$ bromophenol blue and $65 \mathrm{mM}$ DTT, and finally for $15 \mathrm{~min}$ in the same solution except that DTT was replaced by $13.5 \mathrm{mM}$ iodoacetamide. Then, proteins were separated on $12 \%$ SDS-polyacrylamide gels at a constant voltage of $150 \mathrm{~V}$ overnight at $10{ }^{\circ} \mathrm{C}$, using an Iso-DALT electrophoresis unit (Amersham Biosciences, Orsay, France). Gels were stained with silver nitrate or colloidal Coomassie blue. Computer analysis of 2D-PAGE images was performed using Melanie II" software (Bio-Rad, Richmond, USA).

In-gel digestion.- The protocol of ingel digestion is adapted from (11), using a Packard Multiprobe II liquid handling robot (Perkin Elmer, Courtaboeuf, France). Protein spots were excised from colloidal Coomassie blue stained gels, and washed successively with water, $25 \mathrm{mM}$ ammonium bicarbonate, acetonitrile / 25 $\mathrm{mM}$ ammonium bicarbonate $(1: 1, \mathrm{v} / \mathrm{v})$ and acetonitrile. Gel fragments were dried at $37^{\circ} \mathrm{C}$. The digestion was carried out at $37^{\circ} \mathrm{C}$ for 5 hours after addition of $10 \mu \mathrm{L}$ of $0.0125 \mu \mathrm{g} . \mu \mathrm{L}^{-1}$ trypsin in $25 \mathrm{mM}$ ammonium bicarbonate $(\mathrm{pH}$ 7.8). The resulting tryptic fragments were extracted twice with $50 \mu \mathrm{L}$ of acetonitrile / water (1:1, $\mathrm{v} / \mathrm{v}$ ) containing $0.1 \%$ trifluoroacetic acid for $15 \mathrm{~min}$. The pooled supernatants were concentrated to a final volume of $c a .20 \mu \mathrm{L}$ by heating at $37^{\circ} \mathrm{C}$. The tryptic peptides were desalted and concentrated to a final volume of $3 \mu \mathrm{L}$ with $\mathrm{C}_{18}$ Zip-Tip, and immediately spotted onto the MALDI target by the robot.

MALDI-TOF MS analysis.- The $\alpha$ cyano-4-hydroxycinnamic acid matrix was prepared at half saturation in acetonitrile / water $(1: 1, \mathrm{v} / \mathrm{v})$ acidified with $0.1 \%$ trifluoroacetic acid. $0.8 \mu \mathrm{L}$ of each sample was mixed with $0.8 \mu \mathrm{L}$ of the matrix and the mixture was immediately spotted on the MALDI target and allowed to crystallize. The analyses were performed on a BiFlex III MALDI-TOF mass spectrometer (Bruker Daltonics, Bremen, Germany). Reflector spectra were obtained automatically with the AutoXecute ${ }^{\mathrm{TM}}$ mode over a mass range of $700-3500 \mathrm{Da}$ in the short pulsed ion extraction mode using an accelerating voltage of $19 \mathrm{kV}$. Spectra from 200 laser shots were summed 
to generate a peptide mass fingerprint for each protein digest. Two peptide ions generated by the autolysis of trypsin were used as internal standards for calibrating the mass spectra. Automatic annotation of monoisotopic masses was performed using Bruker's SNAPTM procedure.

Identification in database.- The MASCOT search engine software (Matrix Science, London, UK), running on a local server, was used to search the NCBInr database. The following parameters were used for database search : mass tolerance of $50 \mathrm{ppm}$, a minimum of five peptides matching to the protein, and one missed cleavage allowed.

\section{Results}

Whole saliva generates complex proteome maps.- The whole saliva proteome was investigated by two-dimensional gel electrophoresis with the first goal to establish a map giving an overview of proteins present in saliva. For this purpose, pH 3-10 IPG gels and $12 \%$ SDS-polyacrylamide gels were selected in order to separate proteins covering the whole $\mathrm{pI}$ range and a large MW range between 15 and $120 \mathrm{kDa}$. In addition, large format gels $(18 \times 20 \mathrm{~cm})$ were used to improve the resolution. More than 700 protein spots were detected after silver staining of gels loaded with $100 \mathrm{mg}$ of desalted protein (Fig. 1). These proteins covered all the MW range investigated but displayed mainly acidic and neutral pI. In order to characterize these proteins, micro-preparative gels were loaded with $500 \mathrm{mg}$ salivary proteins and stained with colloidal Coomassie blue. The 100 most abundant spots were picked out, digested by trypsin and processed for MALDI-TOF MS fingerprinting. When fixing a mass tolerance of $50 \mathrm{ppm}$, a minimum of five identified peptides per protein, and allowing no more than one missed cleavage, a total of 110 proteins was thus identified. These identifications showed a score that, in average, was $65 \%$ higher than the significance threshold $(p=0.05)$ for the queried databases (Table I). In addition, the average sequence coverage amounted to $37 \%$. Together with the scores and the selected criteria, this argued for confident identification of proteins from their peptide mass fingerprints, including for the few proteins identified in the same spots due to co-migration.

In terms of sequences, the 110 characterized protein spots identified 26 different accessions in the database (Table I): one accession code for human salivary $\alpha$-amylase (42 spots), one for serum albumin (4 spots), four for immunoglobulin chains ( 5 spots), two for myosin chains (6 spots), four for various cystatins (23 spots), one for calgranulin B (1 spot), one for lacrimal lipocalin (2 spots), one for secretory actin-binding protein (6 spots), one for $\alpha$-enolase ( 2 spots), one for glutathione-S-transferase (3 spots), one for zinc $\alpha_{2}$-glycoprotein (5 spots), one for zinc finger protein (1 spot), one for serine proteinase inhibitor (1 spot) and one for an unknown protein (1 spot). Additionaly, it should be noted that the following accessions were identified for the first time in saliva : myosin heavy chain (fast skeletal muscle, IIA and IIB), phosphatidylethanolamine binding protein, secretory actin-binding protein precursor and triosephosphate isomerase.

The saliva proteome includes a number of potentially processed proteins.- MS identification showed that $75 \%$ of accessions were found in several spots. In addition, for ca. $60 \%$ of proteins, the 


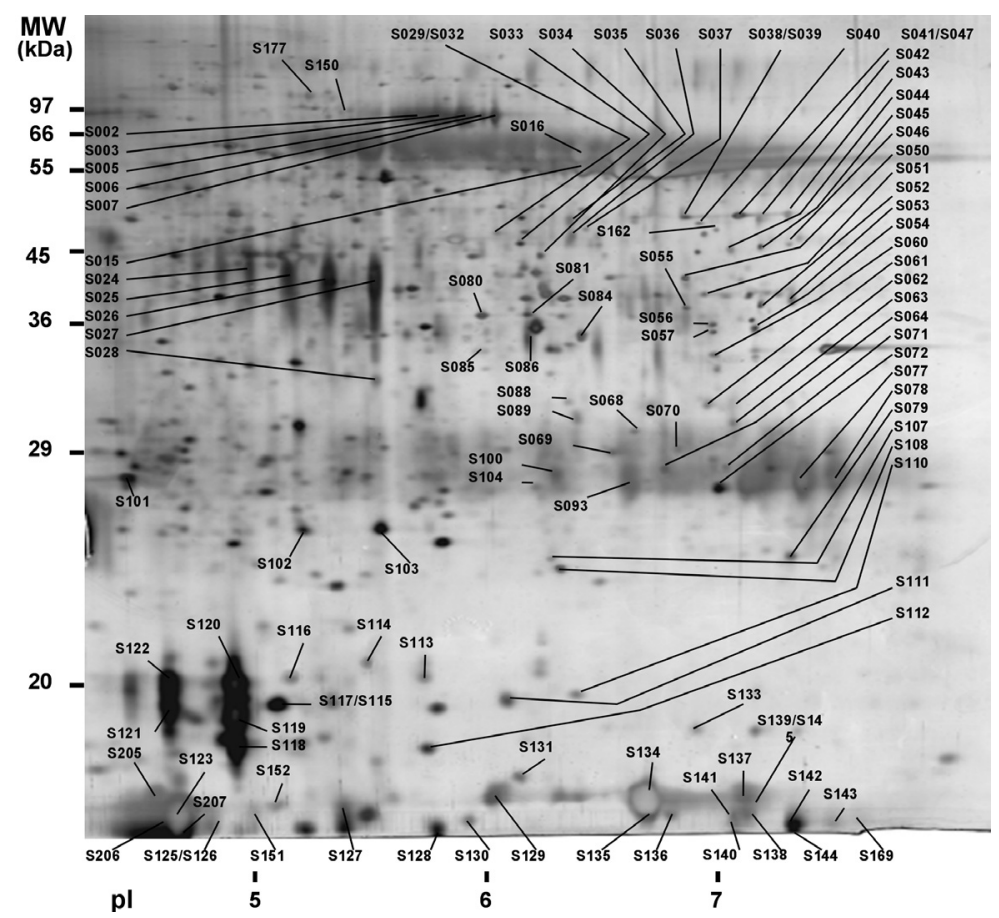

Fig. 1. Two-dimensional map of human salivary proteins.

Proteins were resolved using pH 3-10 NL IPG and $12 \%$ SDS-PAGE and gel was silver stained. Proteins subsequently identified by MALDI-TOF MS are indicated by respective spot numbers. Two different spot numbers are given for comigrating proteins.

Table I. Identified proteins in whole saliva.

Except when indicated protein name, accessions refer to human proteins, according to NCBI and/or SwissProt $\left({ }^{*}\right)$ databases. Sequence coverages are given as percentage (\% cov.). Theoretical (theo.) and observed (obs.) MW and pl values were computed from the protein sequence or deduced from 2D gels.

\begin{tabular}{|c|c|c|c|c|c|c|c|}
\hline \multirow{2}{*}{$\begin{array}{c}\text { Spot } \\
\mathrm{n}^{\circ} \\
\end{array}$} & \multirow[b]{2}{*}{ Protein Name } & \multirow[b]{2}{*}{ Accession } & \multirow[b]{2}{*}{$\%$ cov. } & \multicolumn{2}{|c|}{ MW } & \multicolumn{2}{|c|}{$\mathrm{pl}$} \\
\hline & & & & theo. & obs. & theo. & obs. \\
\hline S002 & serum albumin, chain $A$ & $1 \mathrm{AO} 6 \mathrm{~A}$ & 29 & 69366 & 68000 & 5.63 & 5.2 \\
\hline S003 & serum albumin, chain $A$ & $1 \mathrm{AO6A}$ & 25 & 69366 & 68000 & 5.63 & 5.4 \\
\hline S005 & serum albumin, chain $A$ & $1 \mathrm{AO} 6 \mathrm{~A}$ & 25 & 69366 & 68000 & 5.63 & 5.6 \\
\hline S006 & serum albumin, chain $\mathrm{A}$ & 1AO6A & 27 & 69366 & 68000 & 5.63 & 5.6 \\
\hline S007 & serum albumin, chain $A$ & $1 \mathrm{AO} 6 \mathrm{~A}$ & 25 & 69366 & 68000 & 5.63 & 5.7 \\
\hline S024 & zinc-alpha-2-glycoprotein, chain D (fragments) & 1ZAGD & 52 & 30547 & 44000 & 6.03 & 5.1 \\
\hline S025 & zinc-alpha-2-glycoprotein, chain D (fragments) & ) 1ZAGD & 53 & 30547 & 43000 & 6.03 & 5.2 \\
\hline S026 & zinc-alpha-2-glycoprotein, chain D (fragments) & ) $1 Z A G D$ & 57 & 30547 & 42500 & 6.03 & 5.4 \\
\hline S027 & zinc-alpha-2-glycoprotein, chain D (fragments) & ) 1ZAGD & 53 & 30547 & 42500 & 6.03 & 5.6 \\
\hline S028 & zinc-alpha-2-glycoprotein, chain D (fragments) & ) $1 Z A G D$ & 34 & 30547 & 34000 & 6.03 & 5.6 \\
\hline S029 & myosin heavy chain IIB (fragment) & Q9JHR4 & 31 & 60994 & 45000 & 5.38 & 5.9 \\
\hline
\end{tabular}




\begin{tabular}{|c|c|c|c|c|c|c|c|}
\hline \multirow{2}{*}{$\begin{array}{c}\text { Spot } \\
\mathrm{n}^{\circ}\end{array}$} & \multirow[b]{2}{*}{ Protein Name } & \multirow[b]{2}{*}{ Accession } & \multirow[b]{2}{*}{$\%$ cov. } & \multicolumn{2}{|c|}{ MW } & \multicolumn{2}{|c|}{$\mathrm{pl}$} \\
\hline & & & & theo. & obs. & theo. & obs. \\
\hline S032 & myosin heavy chain (fragment) & Q9JHR4 & 12 & 101955 & 45000 & 5.23 & 6.1 \\
\hline S039 & alpha enolase & P06733 & 40 & 47008 & 47000 & 6.99 & 7.1 \\
\hline S041 & alpha enolase & P06733 & 45 & 47008 & 45000 & 6.99 & 7.8 \\
\hline S061 & cystatin SN precursor & UDHUP2 & 57 & 16351 & 32000 & 6.82 & 6.8 \\
\hline S071 & myosin heavy chain $2 \mathrm{~A}$ (fragment) & 151912 & 19 & 26881 & 28000 & 5.94 & 6.8 \\
\hline S072 & triosephosphate isomerase & P00938 & 34 & 26522 & 26500 & 6.51 & 6.7 \\
\hline S077 & IgG kappa chain (fragment) & BAA37169 & 43 & 23404 & 25000 & 6.92 & 7 \\
\hline S078 & IgG kappa chain (fragment) & BAA37169 & 44 & 23404 & 25000 & 6.92 & 7 \\
\hline S079 & phosphatidylethanolamine binding & & & & & & \\
\hline & binding protein, chain $\mathrm{A}$ & 1BD9A & 60 & 20329 & 24000 & 7.18 & 7.2 \\
\hline S080 & myosin heavy chain IIB (fragment) & Q9JHR4 & 11 & 60994 & 45000 & 5.38 & 5.9 \\
\hline S081 & myosin heavy chain (fragment) & CAA27380 & 11 & 101955 & 36000 & 5.23 & 5 \\
\hline S084 & Ig alpha-1 chain $\mathrm{C}$ region & A1HU & 22 & 37631 & 37000 & 6.08 & 6.3 \\
\hline S085 & myosin heavy chain (fragment) & Q9JHR4 & 11 & 101955 & 36000 & 5.23 & 5 \\
\hline S086 & proteinase inhibitor, clade b & Q96J21 & 10 & 44594 & 35000 & 6.35 & 5 \\
\hline S089 & Ig chain constant region alpha 1 (fragment) & CAC20453 & 16 & 37623 & 33000 & 6.08 & 6.2 \\
\hline S101 & hypothetical 18.9 kda protein & Q96DA0* & 31 & 18867 & 25000 & 5.38 & 4 \\
\hline S102 & glutathione S-transferase P & P09211 & 61 & 23210 & 24000 & 5.44 & 5.5 \\
\hline S103 & glutathione S-transferase $\mathrm{P}$ & P09212 & 61 & 23210 & 24000 & 5.44 & 5.7 \\
\hline S107 & glutathione S-transferase P & P09211 & 46 & 23210 & 23000 & 5.44 & 6.2 \\
\hline S115 & lacrimal lipocalin precursor & LCHUL & 37 & 19250 & 17000 & 5.26 & 4.5 \\
\hline S117 & secretory actin-binding protein precursor & SQHUAC & 26 & 19238 & 18000 & 5.39 & 5.2 \\
\hline S118 & secretory actin-binding protein precursor & SQHUAC & 37 & 19238 & 18000 & 5.39 & 5.1 \\
\hline S119 & secretory actin-binding protein precursor & SQHUAC & 37 & 19238 & 20000 & 5.39 & 5.1 \\
\hline S120 & secretory actin-binding protein precursor & SQHUAC & 37 & 19238 & 20000 & 5.39 & 5.1 \\
\hline S121 & lacrimal lipocalin precursor & LCHUL & 23 & 19250 & 16000 & 5.26 & 4.6 \\
\hline S122 & secretory actin-binding protein precursor & SQHUAC & 37 & 19238 & 21000 & 5.39 & 5 \\
\hline S123 & cystatin S precursor & UDHUP1 & 49 & 16204 & 15000 & 4.95 & 5 \\
\hline S125 & secretory actin-binding protein precursor & SQHUAC & 44 & 19238 & 12000 & 5.39 & 5.2 \\
\hline S126 & cystatin S precursor & UDHUP1 & 42 & 16204 & 12000 & 4.95 & 5 \\
\hline S127 & cystatin A & UDHUP2 & 32 & 16351 & 14000 & 6.82 & 5.2 \\
\hline S128 & calgranulin B & P06702 & 5,71 & 13234 & 13000 & 5.71 & 5.5 \\
\hline S129 & cystatin SN precursor & UDHUP2 & 43 & 16351 & 14000 & 6.82 & 6.1 \\
\hline $\mathrm{S} 130$ & cystatin SN precursor & UDHUP2 & 38 & 16351 & 13000 & 6.82 & 5.8 \\
\hline S131 & cystatin SN precursor & UDHUP2 & 42 & 16351 & 15000 & 6.82 & 5.7 \\
\hline S133 & cystatin SN precursor & UDHUP2 & 41 & 16351 & 16000 & 6.82 & 6.5 \\
\hline S134 & cystatin SN precursor & UDHUP2 & 51 & 16351 & 13000 & 6.82 & 6.5 \\
\hline S135 & cystatin SN precursor & UDHUP2 & 48 & 16351 & 12000 & 6.82 & 6.5 \\
\hline S136 & cystatin SN precursor & UDHUP2 & 38 & 16351 & 13000 & 6.82 & 6.8 \\
\hline S137 & cystatin SN precursor & UDHUP2 & 38 & 16351 & 13000 & 6.82 & 6.8 \\
\hline S138 & cystatin SN precursor & UDHUP2 & 51 & 16351 & 16000 & 6.82 & 6.8 \\
\hline S139 & cystatin B & UDHUB & 55 & 11167 & 11000 & 7.9 & 7.4 \\
\hline S140 & cystatin B & UDHUB & 61 & 11167 & 11000 & 7.9 & 7.4 \\
\hline S141 & cystatin B & UDHUB & 61 & 11167 & 11000 & 7.9 & 7.4 \\
\hline S142 & cystatin SN precursor & UDHUP2 & 41 & 16351 & 15000 & 6.82 & 7.2 \\
\hline S143 & cystatin SN precursor & UDHUP2 & 57 & 16351 & 15000 & 6.82 & 7.2 \\
\hline S144 & cystatin SN precursor & UDHUP2 & 28 & 16351 & 12000 & 6.82 & 7.1 \\
\hline S145 & Ig chain variable region & AAD30836 & 57 & 13816 & 12000 & 9.01 & 7.3 \\
\hline S150 & myosin heavy chain (fragment) & Q9JHR4 & 11 & 101955 & 100000 & 5.46 & 5.5 \\
\hline
\end{tabular}




\begin{tabular}{|c|c|c|c|c|c|c|c|}
\hline \multirow{2}{*}{$\begin{array}{c}\text { Spot } \\
n^{\circ}\end{array}$} & \multirow[b]{2}{*}{ Protein Name } & \multirow[b]{2}{*}{ Accession } & \multirow[b]{2}{*}{$\%$ cov. } & \multicolumn{2}{|c|}{ MW } & \multicolumn{2}{|c|}{$\mathrm{pl}$} \\
\hline & & & & theo. & obs. & theo. & obs. \\
\hline S151 & cystatin SN precursor & UDHUP2 & 42 & 16351 & 14000 & 6.82 & 5.3 \\
\hline S152 & cystatin SN precursor & UDHUP2 & 32 & 16351 & 14000 & 6.82 & 5.4 \\
\hline S169 & cystatin SN precursor & UDHUP2 & 42 & 16351 & 160000 & 6.82 & 8 \\
\hline S177 & myosin heavy chain (fragment) & Q9JHR4 & 29 & 101955 & 95000 & 5.46 & 5.8 \\
\hline S205 & cystatin S precursor & UDHUP1 & 37 & 16204 & 13000 & 4.95 & 4.8 \\
\hline S206 & cystatin S precursor & UDHUP1 & 44 & 16204 & 14000 & 4.95 & 4.8 \\
\hline S207 & cystatin S precursor & UDHUP1 & 44 & 16204 & 14000 & 4.95 & 4.8 \\
\hline S015 & salivary $\alpha$-amylase & 1SMD/P04745* & * 51 & 55746 & 56000 & 6.34 & 6.1 \\
\hline S016 & salivary $\alpha$-amylase & 1SMD/P04745* & * 50 & 55724 & 59000 & 6.45 & 6.1 \\
\hline S033 & salivary $\alpha$-amylase & 1SMD/P04745* & * 26 & 55746 & 45000 & 6.34 & 5.3 \\
\hline S034 & salivary $\alpha$-amylase & 1SMD/P04745* & * 45 & 55746 & 43000 & 6.34 & 5.5 \\
\hline S035 & salivary $\alpha$-amylase & 1SMD/P04745* & * 45 & 55746 & 46000 & 6.34 & 5.6 \\
\hline S036 & salivary $\alpha$-amylase & 1SMD/P04745* & * 51 & 55746 & 45000 & 6.34 & 5.6 \\
\hline S037 & salivary $\alpha$-amylase & 1SMD/P04745* & * 45 & 55746 & 46000 & 6.34 & 5.7 \\
\hline S038 & salivary $\alpha$-amylase & 1SMD/P04745* & * 30 & 55746 & 47000 & 6.34 & 6.8 \\
\hline S040 & salivary $\alpha$-amylase & 1SMD/P04745* & * 46 & 55746 & 46000 & 6.34 & 6.9 \\
\hline S042 & salivary $\alpha$-amylase & 1SMD/P04745* & * 52 & 55746 & 46000 & 6.34 & 7.2 \\
\hline S043 & salivary $\alpha$-amylase & 1SMD/P04745* & * 49 & 55746 & 46000 & 6.34 & 7.4 \\
\hline S044 & salivary $\alpha$-amylase & 1SMD/P04745* & * 18 & 55746 & 44000 & 6.34 & 6.9 \\
\hline S045 & salivary $\alpha$-amylase & 1SMD/P04745* & * 47 & 55746 & 45000 & 6.34 & 7.2 \\
\hline S046 & salivary $\alpha$-amylase & 1SMD/P04745* & * 56 & 55746 & 45000 & 6.34 & 7.5 \\
\hline S047 & salivary $\alpha$-amylase & 1SMD/P04745* & * 28 & 55746 & 46000 & 6.34 & 7.1 \\
\hline S162 & salivary $\alpha$-amylase & 1SMD/P04745* & * 36 & 55746 & 46000 & 6.34 & 6.9 \\
\hline S050 & salivary $\alpha$-amylase & 1SMD/P04745* & * 47 & 55746 & 43000 & 6.34 & 6.8 \\
\hline S051 & salivary $\alpha$-amylase & 1SMD/P04745* & * 48 & 55746 & 42000 & 6.34 & 6.9 \\
\hline S052 & salivary $\alpha$-amylase & 1SMD/P04745* & * 39 & 55746 & 39000 & 6.34 & 7.4 \\
\hline S053 & salivary $\alpha$-amylase & 1SMD/P04745* & * 40 & 55746 & 39000 & 6.34 & 7.5 \\
\hline S054 & salivary $\alpha$-amylase & 1SMD/P04745* & * 43 & 55746 & 36000 & 6.34 & 7.4 \\
\hline S055 & salivary $\alpha$-amylase & 1SMD/P04745* & * 16 & 55746 & 37000 & 6.34 & 6.8 \\
\hline S056 & salivary $\alpha$-amylase & 1SMD/P04745* & * 50 & 55746 & 34000 & 6.34 & 6.4 \\
\hline S057 & salivary $\alpha$-amylase & 1SMD/P04745* & * 49 & 55746 & 33000 & 6.34 & 6.5 \\
\hline S060 & salivary $\alpha$-amylase & 1SMD/P04745* & * 43 & 55746 & 32000 & 6.34 & 6.7 \\
\hline S062 & salivary $\alpha$-amylase & 1SMD/P04745* & * 56 & 55746 & 32000 & 6.34 & 7.1 \\
\hline S063 & salivary $\alpha$-amylase & 1SMD/P04745* & * 53 & 55746 & 30000 & 6.34 & 7.1 \\
\hline S064 & salivary $\alpha$-amylase & 1SMD/P04745* & * 17 & 55746 & 28000 & 6.34 & 6.8 \\
\hline S068 & salivary $\alpha$-amylase & 1SMD/P04745* & * 44 & 55746 & 30000 & 6.34 & 6.4 \\
\hline S069 & salivary $\alpha$-amylase & 1SMD/P04745* & * 40 & 55746 & 29000 & 6.34 & 6.3 \\
\hline S070 & salivary $\alpha$-amylase & 1SMD/P04745* & * 39 & 55746 & 29000 & 6.34 & 6.5 \\
\hline S088 & salivary $\alpha$-amylase & 1SMD/P04745* & * 31 & 55746 & 32000 & 6.34 & 6.1 \\
\hline S093 & salivary $\alpha$-amylase & 1SMD/P04745* & * 47 & 55746 & 28000 & 6.34 & 6.4 \\
\hline S100 & salivary $\alpha$-amylase & 1SMD/P04745* & * 34 & 55746 & 28000 & 6.34 & 5.7 \\
\hline S104 & salivary $\alpha$-amylase & 1SMD/P04745* & * 27 & 55746 & 28000 & 6.34 & 5.6 \\
\hline S108 & salivary $\alpha$-amylase & 1SMD/P04745* & * 19 & 55746 & 25000 & 6.34 & 6.5 \\
\hline S110 & salivary $\alpha$-amylase & 1SMD/P04745* & * 20 & 55746 & 23000 & 6.34 & 6.2 \\
\hline S111 & salivary $\alpha$-amylase & 1SMD/P04745* & * 31 & 33074 & 21000 & 7.56 & 5.9 \\
\hline S112 & salivary $\alpha$-amylase & 1SMD/P04745* & * 19 & 33074 & 18000 & 7.56 & 5.6 \\
\hline S113 & salivary $\alpha$-amylase & 1SMD/P04745* & * 22 & 33074 & 21000 & 7.56 & 5 \\
\hline S114 & salivary $\alpha$-amylase & 1SMD/P04745* & * 18 & 55746 & 22000 & 6.34 & 4.7 \\
\hline S116 & salivary $\alpha$-amylase & 1SMD/P04745* & * 17 & 55746 & 21000 & 6.34 & 4.5 \\
\hline
\end{tabular}


observed MW differed by more than $10 \%$ from its theoretical MW as computed from the corresponding accessions. In the same way, for ca $40 \%$ of proteins, the observed pI differed by more than $10 \%$ from the theoretical one. On another hand, such patterns were observed as well with fresh saliva, that was analysed immediately after collection, as with samples stored for up to 20 days at $-80^{\circ} \mathrm{C}$ or for up to 20 days at room temperature before analysis. In addition, although quantitative variations were found among donors, similar qualitative patterns were found for several healthy donors differing by age and gender (data not shown). Taken together, these observations suggested that the protein composition of whole saliva was stable but quite complex suggesting that a major proportion of the detected proteins could be subjected in vivo to post-translational modification or processing.

\section{Discussion}

Saliva is usually taken as a complex medium, that was recently characterized by proteomic approach $(7,9,20,21)$, allowing the cumulated identification of up to 35 accessions.

In the present work, 26 were detected including 10 novel accessions leading to an enriched picture of the saliva proteome. A main feature raising from the 320 protein spots that were characterized in these works $(7,9,20,21)$, is that the saliva proteome contains a relatively low number of different accessions, but, conversely, spread out over a large number of protein spots (Table II).

Accordingly, 3 kinds of proteins account for two thirds of spots $(\alpha$-amylase, $32 \%$; cystatins, $23 \%$; immunoglobulins, $10 \%$ ) and 3 for another $15 \%$ (albu- min, a zinc- $\alpha_{2}$-glycoprotein and a prolactin-inducible protein). On this point of view, our results amplify the most recent saliva proteomic characterization $(7,9,20)$ and do not support the previous conclusion that major proteins, such as $\alpha$-amylase and albumin, display little if any modification (21).

Nevertheless, a very large redundancy of protein spots is also clear for proteins, such as, for instance, the cystatin family of cysteine protease inhibitors. In this case, a total of 9 accessions is presently identified in 93 protein spots. This diversity is in agreement with recent report based on different separation technique and identifying the presence of several modified or possibly truncated forms from the cystatin family in saliva (15).

In the case of $\alpha$-amylase, 42 characterized protein spots identified accession in the database. Alpha amylase is encoded by a multigene family (1) and constitutes one of the most studied and strongly characterized salivary protein $(12,22)$. The protein is well known to occur into two major forms, one with $56 \mathrm{kDa} \mathrm{MW}$ corresponding to the unglycosylated protein, and another one with $59 \mathrm{kDa} \mathrm{MW}$ corresponding to a glycosylated state (3). The two $\alpha$-amylase spots identified as these two forms, differed by $3 \mathrm{kDa}$ and are part of horizontal series of spots displaying identical MW but different pI. According to the usual interpretation, all these spots could be assumed to exemplify the various isoforms of both glycosylated and unglycosylated $\alpha$-amylases ranging into a pI range between 5 and $8(2,21)$. In this frame, nearly 30 spots might be associated to unglycosylated forms, and at least 20 spots to glycosylated forms. Thus, $\alpha$ amylase appears to display a diversity which is far larger than previously reported $(7,20,21)$. It should be noted that a 
Table II. Present knowledge of the saliva proteome.

Data are from proteomic characterization (21, Yao et al., 2003; 7, Ghafouri et al., 2003; 20, Vitorino et al., 2004; 9, Hu et al., 2005) of the whole saliva by 2D gel electrophoresis and MALDI-TOF MS. Protein names in bold refer to those which were identified only in this work.

\begin{tabular}{|c|c|c|c|c|c|}
\hline Protein Name & $\begin{array}{l}\text { Yao } \\
\text { et al. }\end{array}$ & $\begin{array}{l}\text { Ghafouri } \\
\text { et al. }\end{array}$ & $\begin{array}{c}\text { Vittorino } \\
\text { et al. }\end{array}$ & $\begin{array}{l}\mathrm{Hu} \\
\text { et al. }\end{array}$ & $\begin{array}{c}\text { present } \\
\text { work }\end{array}$ \\
\hline alpha-amylase & 3 & 27 & 5 & 38 & 42 \\
\hline alpha-enolase & & & 1 & 1 & 2 \\
\hline beta2-microglobulin & & 1 & 1 & & \\
\hline Actin beta & & & & 4 & \\
\hline Alpha fetoprotein & & & & 6 & \\
\hline Anti Entamoeba histolytica immunoglobulin kappa light chain & & & & 1 & \\
\hline Anti HBs antibody light-chain Fab (fragment) & & & & 1 & \\
\hline Anti TNF-alpha antibody light-chain Fab & & & & 1 & \\
\hline Apolipoprotein A1 & & 2 & 1 & & \\
\hline Beta galactosidase precursor & & & & 1 & \\
\hline Ig M heavy chain (fragment) & & & & 1 & \\
\hline Calgranulin A & 1 & 1 & 1 & & \\
\hline Calgranulin B & & 4 & 2 & & 1 \\
\hline Carbonate dehydratase VI precursor & & & & 6 & \\
\hline carbonic anhydrase VI & & & 1 & & \\
\hline Cystatin A & & & 1 & & 1 \\
\hline Cystatin B & & & 1 & & 3 \\
\hline Cystatin C & & & 1 & & \\
\hline Cystatin D & & 3 & 1 & & \\
\hline Cystatin S & & 9 & 1 & 2 & 5 \\
\hline Cystatin SA & 1 & 8 & 1 & 1 & 1 \\
\hline Cystatin SA-III & 1 & & 1 & & \\
\hline Cystatin SN & 2 & 2 & 3 & 3 & 16 \\
\hline cystein-rich secretory protein 3 & & & 1 & & \\
\hline Cytokeratin 16 & & & & 1 & \\
\hline Cytokeratin $2 \mathrm{e}$ & & & & 1 & \\
\hline Cytokeratin 4 & & & & 1 & \\
\hline Cytokeratin 6Aa & & & & 3 & \\
\hline Desmin & & & & 1 & \\
\hline DnaK-type molecular chaperone & & & & 1 & \\
\hline DnaK-type molecular chaperone HSP70 & & & & 1 & \\
\hline Fatty acid binding protein & & 1 & 1 & 1 & \\
\hline Fibrinogen beta chain precursor & & & & 2 & \\
\hline Fructose-bisphosphate aldolase & & & & 1 & \\
\hline Glutathione S-Transferase P & & 1 & 1 & 1 & 3 \\
\hline Glutathione synthase & & & & 1 & \\
\hline Glyceraldehyde-3-phosphate dehydrogenase & & & & 2 & \\
\hline Hemopexin precursor & & & & 2 & \\
\hline histatin 1 & & & 1 & & \\
\hline histatin 3 & & & 1 & & \\
\hline Hypothetical 18.9 kDa protein & & & & & 1 \\
\hline Ig alpha-1 chain $\mathrm{C}$ region & & & & 3 & \\
\hline Ig alpha-2 chain $\mathrm{C}$ region & & & & 1 & \\
\hline Ig heavy chain constant region alpha 1 (fragment) & & & & 3 & \\
\hline Ig mu chain $\mathrm{C}$ region & & & & 1 & \\
\hline Iga1 chains $a$ and $b$, heavy, chains $c$ and $d$, light, chain $A$ & & & & 3 & \\
\hline
\end{tabular}




\begin{tabular}{|c|c|c|c|c|c|}
\hline Protein Name & $\begin{array}{l}\text { Yao } \\
\text { et al. }\end{array}$ & $\begin{array}{c}\text { Ghafouri } \\
\text { et al. }\end{array}$ & $\begin{array}{c}\text { Vittorino } \\
\text { et al. }\end{array}$ & $\begin{array}{l}\mathrm{Hu} \\
\text { et al. }\end{array}$ & $\begin{array}{c}\text { present } \\
\text { work }\end{array}$ \\
\hline Immunoglobilin k-chain & & 1 & 1 & 1 & 2 \\
\hline Immunoglobulin A secretory chain & & 6 & & & 1 \\
\hline Immunoglobulin $\mathrm{A}$ a-chain $\mathrm{C}$ region & & 6 & 1 & & 1 \\
\hline Immunoglobulin chain constant region a1 & & & & & 1 \\
\hline Immunoglobulin chain variable & & & & & 1 \\
\hline Immunoglobulin J chain & & 3 & 1 & & \\
\hline Interleukin receptor antagonist protein & & 3 & 1 & & \\
\hline Lacrimal lipocalin precursor & & 4 & 1 & & 2 \\
\hline lactoferrin & & & 1 & & \\
\hline Lipocortin I & & & & 2 & \\
\hline L-lactate dehydrogenase, chain $\mathrm{H}$ & & & & 1 & \\
\hline Lysozyme C & & 1 & 1 & & \\
\hline Myosin heavy chain fast skeletal muscle & & & & & 5 \\
\hline Myosin heavy chain IIA & & & & & 1 \\
\hline Myosin heavy chain IIB & & & & & 2 \\
\hline parotid secretory protein & & & 1 & & \\
\hline Phosphatidylethanolamine binding protein & & & & & 1 \\
\hline Phosphatidylinositol transfer protein alpha isoform & & & & 1 & \\
\hline Phosphoglycerate kinase & & & & 1 & \\
\hline PLUNC & & & 1 & & \\
\hline Prolactin inducible protein & & 11 & 1 & 4 & \\
\hline Proteasome subunit, alpha type 3 & & & & 1 & \\
\hline Protein-glutamine gamma-glutamyltransferase & & & & 2 & \\
\hline Hepatocellular carcinoma associated protein & & & & 1 & \\
\hline Secretory actin-binding protein precursor & & & & & 6 \\
\hline Secretory component precursor & & & & 6 & \\
\hline Sequence 19 from Patent & & & & 4 & \\
\hline Sequence 48 from Patent & & & & 1 & \\
\hline Sequence 50 from Patent & & & & 1 & \\
\hline Serine/cysteine proteinase inhibitor, clade B & & & & & 1 \\
\hline Serum albumin & 1 & 4 & 1 & 9 & 5 \\
\hline SNC66 protein & & & & 1 & \\
\hline Statherin & 1 & & 1 & & \\
\hline Stratifin & & & & 1 & \\
\hline Transferrin precursor & & & & 4 & \\
\hline Transketolase & & & & 1 & \\
\hline Triosephosphate isomerase & & & & & 1 \\
\hline Zinc- $\alpha 2$-glycoprotein & & 5 & 2 & 6 & 5 \\
\hline
\end{tabular}

similar situation was recently described in plants, for $\alpha$-amylase from germinating barley seeds (18).

For most $\alpha$-amylase spots that are observed at various MW lower than expected, other mechanisms must be taken into account. One such source of diversity of $\alpha$-amylase patterns was recently assumed to rely on degradations resulting in truncated forms, either in the $\mathrm{N}$-terminal or in the C-terminal region, with molecular weights spanning between $19 \mathrm{kDa}$ and $35 \mathrm{kDa}$ (21). Since protease inhibitors were added during the collection and storage, it should be emphasized that the possible degradations observed 
for $\alpha$-amylase pattern could occur in the oral cavity, despite the abundance of protease inhibitors in saliva (cystatins, clade B; $c$. one quarter of identified spots; 7,9 , $21,22)$. Perhaps the most intriguing situation corresponds to spots that possess peptides in both the N-terminal and Cterminal regions, but display $\mathrm{MW}$ on gel that is $25 \%$ to $50 \%$ lower than expected, suggesting the occurrence of internal deletions. In the absence of complementary knowledge about alternative processing mechanisms in proteins, the elucidation of the origin of such internal deletions remains a challenge.

In conclusion, with respect to the contradiction recently raised by the first proteomic characterizations of saliva $(7,9,20$, 22), our data identify several proteins previously not reported in saliva and argue in favour of a complex proteome. This complexity appears to result from two opposite features: a relatively limited diversity of observed accessions, but counterbalanced by a large redundancy of corresponding spots. A prominent illustration is given by $\alpha$-amylase that occurs in several spots. This unexpected complexity could be the result of the interplay of (post-) transcriptional processes and many post-translational events, including internal deletions by a presently unknown mechanism. Moreover, this diversity could offer the basis for using saliva in non invasive diagnostic of disease.

\section{Acknowledgements}

This work was supported by I.F.R.O grants and benefited of the support of the proteomics platform from the Montpellier Languedoc-Roussillon Genopole. Authors thank Dr. J. Valcarcel for his help in the redaction of the manuscript.

C. HIRTZ, F. CHEVALIER, D. CENTENO, J. C. EGEA, M. ROSSIGNOL N. SOM-
MERER y DEVILLE DE PÉRIÈRE. Complejidad del proteoma de la saliva bumana. J. Physiol. Biochem., 61 (3), 469-480, 2005.

Las recientes caracterizaciones del proteoma salival completo han llevado a resultados contradictorios. En este trabajo, se han analizado 110 proteínas por espectrometría de masas, lo que ha permitido la identificación de 10 nuevas no detectadas anteriormente en los mapas proteínicos bi-dimensionales. Incluyen cadena pesada de miosina (músculo esquelético rápido, IIa y IIb); proteína de unión a fosfatidiletanolamina, precursor de la proteína secretora de la unión a la actina y triosafosfato isomerasa. Una comparación más precisa con los datos de los estudios precedentes demuestra una baja diversidad en la variedad de accesos y una alta complejidad en el número de bandas correspondientes al mismo acceso. Los dos tercios de las bandas identificadas corresponden a amilasas, cistatinas e inmunoglobulinas. Esta diversidad puede ser de interés en el desarrollo de técnicas de diagnósticos no invasivas.

Palabras clave: Saliva, Maduración proteica, Proteómica, Espectroscopía de masas, Humanos.

\section{References}

1. Bank, R. A., Hettema, E. H., Muijs, M. A., Pals, G., Arwert, F., Boomsma, D. I. and Pronk, J. C. (1992): Hum. Genet., 89, 213-222.

2. Beeley, J. A. and Khoo, K. S. (1999): Electrophoresis, 20, 1652-1660.

3. Beeley, J. A., Sweeney, D., Lindsay, J. C., Buchanan, M. L., Sarna, L. and Khoo, K. S. (1991): Electrophoresis, 12, 1032-1041.

4. Bradford, M. (1976): Anal. Biochem., 72, 248254.

5. Chen, Y. C., Li, T. Y. and Tsai, M. F. (2002): Rapid. Commun. Mass. Spectrom., 16, 364-369.

6. Fabian, T. K., Gaspar, J., Fejerdy, L., Kaan, B., Balint, M., Csermely, P. and Fejerdy, P. (2003): Med. Sci. Monit., 9, 62-65.

7. Ghafouri, B., Tagesson, C. and Lindahl, M. (2003): Proteomics, 3, 1003-1015.

8. Gygi, S. P., Corthals, G. L., Zhang, Y., Rochon, Y. and Aebersold, R. (2000): Proc. Natl. Acad. Sci., 97, 9390-9395. 
9. Hu, S., Xie, Y., Ramachandran, P., Ogorzalek Loo, R. R., Li, Y., Loo, J. A. and Wong, D. T. (2005): Proteomics, 5, 1714-1728.

10. Humphrey, S. P. and Williamson, T. A. (2001): J. Prosthet. Dent., 85, 162-169.

11. Jensen, O. N., Wilm, M., Shevchenko, A. and Mann, M. (1999): Methods. Mol. Biol., 112, 513530.

12. Kandra, L. and Gyemant, G. (2000): Carbohydr. Res., 329, 579-585.

13. Kauffman, D. L., Watanabe, S., Evans, J. R. and Keller, P. J. (1973): Archs. Oral. Biol., 18, 11051111.

14. Lac, G. (2001): Pathol. Biol., 49, 660-667.

15. Lupi, A., Messana, I., Denotti, G., Schinina, M. E., Gambarini, G., Fadda, M. B., Vitali, A., Cabras, T., Piras, V., Patamia, M., Cordaro, M., Giardina, B. and Castagnola, M. (2003): Proteomics, 3, 461-467.
16. Mandel, I.D. (1989): J. Am. Dent. Assoc., 119, 298-304.

17. Musumeci, V., Cherubini, P., Zuppi, C., Zappacosta, B., Ghirlanda, G. and Di-Salvo, S. (1993): J. Oral. Pathol. Med., 22, 73-76.

18. Ostergaard, O., Melchior, S., Roepstorff, P. and Svensson, B. (2002): Proteomics, 2, 733-739.

19. Todd, A. L., Ng, W. Y., Lee, Y. S., Loke, K. Y. and Thai, A. C. (2002): Diab. Res. Clin. Pract., 57, 171-177.

20. Vitorino, R., Lobo, M. J., Ferrer-Correira, A. J., Dubin, J. R., Tomer, K. B., Domingues, P. M. and Amado, F. M.(2004): Proteomics, 4, 11091115.

21. Yao, Y., Berg, E. A., Costello, C. E., Troxler, R. F. and Oppenheim, F. G. (2003): J. Biol. Chem., 278, 5300-5308.

22. Zakowski, J. J. and Bruns, D. E. (1985): Crit. Rev. Clin. Lab. Sci., 21, 283-324. 